\title{
Urolithiasis (Kalladaippu) - An Evidence Based Case Study
}

\section{Case Study}

\section{Sathiyarajeswaran $\mathbf{P}^{1}$, Shree Devi $M S^{2^{*}}$, Siva Lakshmi $S^{3}$, Daniya Francis ${ }^{3}$}

1. Assistant Director, Scientist - II \&I/c, 2. Research officer, Siddha Central Research Institute, Chennai. 3. CRRI, Santhagiri Siddha Medical College, Trivandrum.

\begin{abstract}
"KALLADAIPPU" (Urolithiasis) "KALPIRAMIYAM'(Urolithiasis) are the synonyms in Siddha and the term equated to renal calculi in allopathic system of medicines. An increasing affluence and adaptation of Western diet habits in many developing countries seem likely to contribute to the changes for the development of renal calculi. Siddha medicine describes certain formulations as Lithotriptic and diuretic which is used in the treatment of renal calculi successfully. This case reported again is an example that proves the efficacy of Siddha medicines for expulsion of renal stones. The synergistic action enhanced resulting in disintegration and elimination of urinary stones from urinary tract.
\end{abstract}

Keywords: Kalladaippu, Kalpiramiyam, Urolithiasis, Renal calculi, Siddha medicine, Case study.

\section{Introduction:}

"KALLADAIPPU"

"KALPIRAMIYAM" (Urolithiasis) (2) are the synonyms in Siddha and the term equated to renal calculi in allopathic system of medicines. "KALPIRAMIYAM" is characterized by whitish discharge from the penis, Osmidrosis, Difficulty in micturition, Pain and swelling in lower abdomen, Pain radiating from umbilicus to scrotum, Loss of appetite. Urolithiasis remains a disease with a clear predominance in males for all stone compositions except for infective stones. Although calculus disease is still more prevalent in men than women, Now-a-days females seem more likely to be affected than previously. This seems in varying degrees true for both the developed and the developing countries. People in the latter are more likely to develop kidney calculi at younger ages though. Many factors including aging of the population, changes in diet, global warming, and employment of more accurate diagnostic tools seem to be involved in this increase. An increasing affluence and adaptation of Western diet habits in many developing countries seem likely to contribute to the changes [3). "KALLADAIPPU" is characterized by obstruction while passing urine,

\footnotetext{
*Corresponding Author:

\section{Shree Devi M S}

Research officer (S),

Siddha Central Research Institute,

Chennai

E-mail Id: shreemd@gmail.com

Phone no: +91-9443056180
}

pain in the tip of penis, burning micturition, renal pain, low back pain, small sand like crystals present in urine. Kalladaippu is caused due to intake of impure stagnant water, increased carbohydrate food and food that increases Vali humour and controlling of semen. Based on body humours kalladaippu is classified into four types like Vali kalladaippu, Azhal kalladaippu, Iya kalladaippu and Mukkuttra kalladaippu. Vali kalladaippu characterized by pricking pain around the umblical region, obstruction of urine during micturition, mucus membrane present in the urine, pain and swelling present in penis due to this pain patient unable to sit, dyspnoeic in nature. Azhal kalladaippu is characterized by burning sensation present in the urethra and whole body, haematuria, red colour small stones present in the urine. Iya kalladaippu pain present in the umbilicus, hip region and thigh, sweating present in the penis, white colour stones present in the urine. Mukkutra kalladaippu characterized by severe pain present in the lower part of the urethra, a fistful stone with semen present in urine per day. In allopathic system, renal calculi is characterized by acute loin to groin colicky pain associated with nausea and vomiting. These symptoms combined with renal angle tenderness and microscopic hematuria are highly predictive of urinary tract stone disease stone disease with a sensitivity of $84 \%$ and a specificity of $99 \%$. One third of incidental stones may become symptomatic. With hydration and pain control, calculi smaller than $5 \mathrm{~mm}$ pass spontaneously in approximately $90 \%$ of patients (4). The rate of stone passage decreases as the stone size increases; a $10 \mathrm{~mm}$ stone has $<10 \%$ chance of passing without surgical intervention. The efficacy 
of invasive therapies, such as extracorporeal shock wave lithotripsy and ureteroscopy, has been proven by several studies $(5,6)$. Nevertheless, these techniques are not risk-free, are problematic, and quite expensive. Siddha describes certain drugs as Lithotriptic, and diuretic which is used in the treatment of renal calculi successfully. There are certain formulations which are mentioned in literature are as follows

\begin{tabular}{|c|c|c|}
\hline S.No & Form of drug & Drug name \\
\hline 1 & Tablets & $\begin{array}{l}\text { Kalludai kudori (7) } \\
\text { Salotharimani (7) } \\
\text { Jalamanjiri (7) } \\
\text { Kalkarachi (7) }\end{array}$ \\
\hline 2 & Chunnam & Vediuppu chunnam(8) \\
\hline 3 & Parpam & $\begin{array}{l}\text { Viral meen thalikal } \\
\text { parpam (7) } \\
\text { Sangu parpam (7) } \\
\text { Muthuchippi parapam } \\
\text { (9) } \\
\text { Silasathu parpam (7) } \\
\text { Karasooda sathu par- } \\
\text { pam(10) } \\
\text { Kukkil parpam (7) } \\
\text { Nandukkal parapam } \\
(11,12,13) \text { }\end{array}$ \\
\hline 4 & Chendooram & $\begin{array}{l}\text { Vediannabedi chen- } \\
\text { dooram (7) } \\
\text { Vediuppu chendooram } \\
\text { (7) } \\
\text { Velli chendooram (7) } \\
\text { Rasa chendooram (7) }\end{array}$ \\
\hline 5 & Chooranam & $\begin{array}{l}\text { Sirupeelai (Aerva La- } \\
\text { nata)(7) } \\
\text { Nerunjil (Tribulus ter- } \\
\text { restris) (14) } \\
\text { Maavilanga paatai } \\
\text { (Crataeva nurvala) (7) }\end{array}$ \\
\hline 6 & $\begin{array}{l}\text { Kudineer } \\
\text { chooranam }\end{array}$ & $\begin{array}{l}\text { Neer mulli Kudineer } \\
\text { chooranam (7) } \\
\text { Nerunjil (Tribulus ter- } \\
\text { restris) Kudineer } \\
\text { chooranam.(14) }\end{array}$ \\
\hline
\end{tabular}

The above said formulations, herbs and minerals which makes the treatment easier without any side effect and also minimizing the risk of recurrence and cost effective when compared to allopathic system of medicines. Literatures show effectiveness of Siddha medicine in expulsion of moderate to big sized renal stones (15). This case reported here is such an example which again proves the importance of individualization and thus efficacy of siddha medicines in addressing the underlying cause and expulsion of renal stone.
Case History:

A 43 year female patient presented with complaints of recurrent attack of mild to moderate dull aching, burning pain in right side of abdomen (right hypochondria) \& back (lumbar region), abdomen pain associated with difficulty in urination for last 2 months. The pain aggravates on motion and ameliorates on rest. The patient developed the complaints gradually. There was no specific compliant in the past. There was no history of diabetes mellitus or hypertension. Diet history reveals that her food intake was irregular. Her vitals were within normal limits. On examination of the abdomen, there was no organomegaly but tenderness elicited on both sides of the lumbar region and left side of renal angle. As advised, Patient underwent Ultrasongraphy of the Abdomeno-pelvic region on 17th August 2016, and the report revealed that three calculi measuring $5 \mathrm{~mm}$ and $4 \mathrm{~mm}$ each were noticed in right kidney in the upper, middle and lower calyces along with $5 \mathrm{~mm}$ calculi in the left Kidney in middle and lower calyces and confirmed that it was Bilateral renal calculi. Her Blood and Urine reports were within normal limits.

The medicines administered for the patient are as follows,

\begin{tabular}{|c|c|c|c|c|}
\hline $\begin{array}{l}\text { S. } \\
\text { No }\end{array}$ & $\begin{array}{l}\text { Name of } \\
\text { the medi- } \\
\text { cine }\end{array}$ & $\begin{array}{c}\text { Dose / } \\
\text { time }\end{array}$ & $\begin{array}{c}\text { Adju- } \\
\text { vant }\end{array}$ & Days \\
\hline 1 & $\begin{array}{l}\text { Kukkil } \\
\text { parpam }\end{array}$ & $\begin{array}{c}500 \\
\mathrm{mg} / \\
\mathrm{BD}\end{array}$ & $\begin{array}{l}\text { Tender } \\
\text { coconut }\end{array}$ & $\begin{array}{c}1 \\
\text { month }\end{array}$ \\
\hline 2. & $\begin{array}{l}\text { Neermulli } \\
\text { Kudineer }\end{array}$ & $\begin{array}{c}60 \mathrm{ml} / \\
\mathrm{BD}\end{array}$ & - & $\begin{array}{c}3 \\
\text { months }\end{array}$ \\
\hline 3. & $\begin{array}{c}\text { Kalkarachi } \\
\text { mathirai }\end{array}$ & $\begin{array}{c}500 \\
\mathrm{mg} / \\
\mathrm{BD}\end{array}$ & Water & $\begin{array}{c}3 \\
\text { months }\end{array}$ \\
\hline 4. & $\begin{array}{c}\text { Amirthathi } \\
\text { kuligai }\end{array}$ & $\begin{array}{c}500 \\
\mathrm{mg} / \\
\mathrm{BD}\end{array}$ & Water & $\begin{array}{c}2 \\
\text { months }\end{array}$ \\
\hline
\end{tabular}

The above unique drugs described in siddha system was administered to her.

During her first follow up, it was noticed that all the clinical features were moderately reduced and in second follow up the clinical features were absent except for pain abdomen, which was less in intensity. In third follow up she was advised to repeat Ultrasonography abdomen and pelvis on 07 -12- 2016. Report reveals that, there was absolutely no calculus in the urinary tract. This shows that, the right renal calculus was also expelled out.

Later she was advised to adhere to Pathyam (diet regimen) food chart upto next visit. And after that the patient was sent for another scan (25-12-16)and the report proved that, there was no recurrence of new stone formation in any part of the urinary tract.

\section{Discussion}

Insulin resistance plays a key role in type 2 diabetes mellitus (DM), and it has been linked to uric acid stone formation $(16,17)$. Insulin resistance might 
result in a deficit in ammonium production in the kidney, which lowers urinary $\mathrm{pH}$, thus generating a favourable milieu for uric acid stone formation. A significant percentage of hypertensive subjects has a greater risk of renal stone formation, especially when hypertension is associated with excessive body weight. Higher oxaluria and calciuria as well as supersaturation of calcium oxalate and uric acid appear to be the most important (18). Observation studies including $>200000$ stone analyses, this difference increased over the observation period with a 2.7:1 male-to-female ratio for the most common calcium-containing calculi.(19).

The synergistic action of the above drugs helps in disintegration and elimination of urinary stones from urinary tract. As they are kattrugalakki (lithotriptic) and neer perukki (diuretic). They help in increasing the vatham which was diminished and there is reduction of pain. The above said treatment package will cost not more than 1000 to 1500 Indian rupees whereas on the other hand the government fixed rate for lithotripsy is around 19500 Indian rupees.

\section{Conclusion}

It is concluded that from the observation made in this study, Siddha could be a cost effective and efficacious treatment option in combating Urolithiasis. However a larger sample size study or case series is mandatory to further substantiate the claim.

\section{References}

1. Yugi vaidhaya chindhamani-800.1952. 89p.

2. Dr N Kuppusamy Mudaliar, Siddha maruthuvam pothu. 1st ed..Directorate of Indian medicine and Homeopathy; 2007.461p.

3. Alatab S, Pourmand G, El Howairis ME, Buchholz N, Najafi I, Pourmand MR, Mashhadi R, Pourmand $\mathrm{N}$, National Profiles of Urinary Calculi. Iranian journal of kidney diseases. March,2016;10(2).

4. Malvinder S Parmar, Kidney stones. BMJ. June 2004 ; 328(7453); 1420-1424.

5. Miller NL, Lingeman JE, Management of kidney stones.. Bmj. March, 2007;334(7591);468-72.

6. Shafi H, Moazzami B, Pourghasem M, Kasaeian A, An overview of Treatment options for urinary stones. Caspian journal of internal medicine. 2016;7 (1);11.

7. K.N.Kuppusamy mudaliyar. Siddha maruthuvam (Podhu). Indian medicine - Homoeopathy department;2012.467,468p.
8. R. Selvam, P. Kalaiselvi, A. Govindaraj, V. Bala Murugan, A. S. Sathish Kumar, Effect of A. lanata leaf extract and Vediuppu chunnam on the urinary risk factors of calcium oxalate urolithiasis during experimental hyperoxaluria. Pharmacol Res. January,2001; 43(1); 89-93.

9. Rajalakshmi P, Analaytical studies on Muthuchippi parpam. Journal on pharmacy research. 2010; 3(10); 2366-2370.

10.Sudha Revathy Sudarsanam, Murugesan Moonandi, Potency of Kara sooda sathu parpam A herbo mineral siddha drug in the management of Kalladaippu noi(Urolithiasis) A drug review. Int.J.Res.Ayurveda Pharm.2014;5(3); 372-379.

11.Sofia HN, Manickavasakam K, A Pilot Study Evaluating Therapeutic Efficacy of Siddha Formulation 'Nandukkal Parpam'in the Management of Renal Calculi. Current Traditional Medicine. September,2015; 1(2);98-102.

12.Kannan, Muthiah, P Sathiyarajeswaran, S Natarajan, Management of Kalladaippu (Renal Calculi). 2012.

13.S Natarajan, C Anbarasi, P Sathiyarajeswaran, MKannan, Nandukkal, a fossil crab used in Siddha Medicine and itstherapeutic usage - a review. Malaya Journal of Biosciences. 2015; 2(2);110-114.

14.Satish S, Periasamy P, Namasivayam A, Effect of Tribulus terrestris on experimental urolithiasis induced by ethylene glycol in albino rats. Pharmacy and Pharmacology Communications. September,1996; 1;2(9):437-9.

15.Nalini Sofia $\mathrm{H}$ and Manickavasakam K.A Pilot Study Evaluating Therapeutic Efficacy of Siddha Formulation 'Nandukkal Parpam' in the Management of Renal Calculi. Current Traditional Medicine, 2015; 98-102.

16.Pak CY, Sakhaee K, Moe Q, et al. Biochemical profile of stone-forming patients with diabetes mellitus. Urology. 2003;61;523-527.

17.Abate N, Chandalia M, Cabo-Chan AV, Jr, et al. The metabolic syndrome and uric acid nephrolithiasis: novel features of renal manifestation of insulin resistance. Kidney Int. 2004;65;386-392.

18.Borghi L, Meschi T, Guerra A, Briganti A, Schianchi T, Allegri F, Novarini A. Essential arterial hypertension and stone disease. Kidney international. June,1999;55(6);2397-406.

19.Knoll T, Leusmann DB, Fahlenkamp D, WendtNordahl G, Schubert G, Urolithiasis through the ages - data from more than 200,000 stone analyses. J Urol. April,2011;185(4);1304-11. 